Creative commons User License: CC BY-NC-ND

Abstracted by: EBSCOhost, Electronic Journals Service (EJS),

Google Scholar, Journal Seek, Scientific Commons,

Food and Agricultural Organization (FAO), CABI and Scopus
Journal of Agricultural Extension

Vol. 22 (3) October, 2018

ISSN(e): 24086851; ISSN(Print); 1119944X

http://journal.aesonnigeria.org

http://www.ajol.info/index.php/jae

Email: editorinchief@aesonnigeria.org

\title{
Agricultural and Nutritional Information Needs of Arable Crop farmers in Ondo State Nigeria.
}

https://dx.doi.org/10.4314/jae.v22i3.2

\section{Olaniyi, Olumuyiwa Akin*.}

Department of Agricultural Extension and Rural Development

Ladoke Akintola University of Technology P.M.B. 4000, Ogbomoso, Nigeria

Email: oaolaniyi@lautech.edu.ng

Phone: 08060202639

\section{Ogunkunle, Tajudeen}

Department of Agricultural Extension and Rural Development

Ladoke Akintola University of Technology P.M.B. 4000, Ogbomoso, Nigeria

Email: ogunkunletajudeen@gmail.com

Phone: 08029411206

${ }^{*}$ Corresponding Author

\section{Abstract}

The study assessed arable crop farmers' agricultural and nutritional information needs in Ondo State, Nigeria. Multistage sampling technique was used in selecting a total sample of 212 farmers for the study. Data were collected through the use of interview schedule. Frequency counts, percentages, mean and analysis of variance (ANOVA) were used to analyze data. Findings showed that the mean age of the farmers was 52.2 years. The majority (84.0\%) of the respondents were male, married with low level of education and farm size. The mean household size was 6 members. The sources of agricultural and nutritional information explored by the respondents are: extension agents, mobile phone, friends and neighbors as well as radio. The respondents indicated their agricultural and nutritional information needs as to include climate and weather forecast ( $\overline{\mathrm{X}}=1.88)$, location and availability of inputs $(\overline{\mathrm{X}}=1.63)$, information on food safety and hygiene $(\overline{\mathrm{X}}=$ 1.61), information on markets where farm produce are exchanged for other farm

produce $(\overline{\mathrm{X}}=1.55)$ and disease control $(\overline{\mathrm{X}}=1.50)$. The result of ANOVA revealed that there exists significant difference in agricultural and nutritional information needs of the respondents across the selected agricultural zones ( $F=$ 5.137, $P \leq 0.05$ ). Information dissemination and delivery to farmers should be targeted toward the identified information needs in order to enhance their capabilities for optimum agricultural production.

Keywords: Information needs, agricultural and nutritional information, crop farmers, Nigeria 
Creative commons User License: CC BY-NC-ND

Abstracted by: EBSCOhost, Electronic Journals Service (EJS),

Google Scholar, Journal Seek, Scientific Commons,

Food and Agricultural Organization (FAO), CABI and Scopus
Journal of Agricultural Extension

Vol. 22 (3) October, 2018

ISSN(e): 24086851; ISSN(Print); $1119944 X$

http://journal.aesonnigeria.org

http://www.ajol.info/index.php/iae

Email: editorinchief@aesonnigeria.org

\section{Introduction}

Information is a vital resource that determines success or otherwise in one's life endeavours or work activities. It equips one with the knowledge needed to overcome challenges and take the appropriate step at the right time. According to Ukachi (2015) and Chen, Liu and Yang (2011), information has been generally accepted as an important resource for individual growth and survival. It is the realization of the place of information in goal's attainment that recently gave it the position of the fifth factor of production. Every individual, notwithstanding the professional affiliation, needs information to excel in his area of specialization including farming. Access to information and the creation of knowledge are key drivers of social and economic transformation. In agriculture for example, new information and knowledge can fuel adoption of innovation and increase productivity.

The ability of farmers to participate in and benefit from growth in the sector is linked to their ability to adopt new practices, solve problems and embed themselves dynamically in agricultural value chains. Farmers, both men and women, need to be connected to the communication channels through which appropriate information is flowing. Farmers currently access information through a complex web of social networks that include other farmers, family members, extension agents and input supply dealers. Yet for many farmers, these networks lack the type of information that can help them to move confidently into more productive strategies and improve their nutritional status (Ukachi and Ayiah, 2017). There is a link between agriculture and nutrition. Information is therefore the bridge that connects the two together. It is an important resource for all agricultural activities and required for increased agricultural productivity that can promote good nutrition as well as address the problem of hunger and poverty in the nation. According to Fahmida (2015), increased agricultural productivity can improve nutrition in several ways. Programmes that directly interact with farmers can deliver significant information about practices and behaviours that improve nutrition, alongside with information on agriculture.

There are varying sources of information available to farmers. Bello and Obinne (2012) opined that agricultural information sources cover all published and unpublished knowledge on general aspects of agriculture and consists of innovations, ideas, technologies, and agricultural policies. These sources are accessed by farmers via different communication channels. It must be emphasized that the viability of a source depends on its ability to satisfy the information needs of the users. Ukachi (2007) emphasized that the speculated and realistic benefit desirable from a source makes that source useful and sustainable. Presently, the prevailing existing sources of information used by farmers include; radio, television, trade associations, age group, extension workers, friends, relatives, posters, handbills, pamphlets and mobile phones (Olajide 201;1 Adio et al 2016). However, recent studies that investigated agricultural information use by farmers still found that the majority of these information sources are grossly underutilized by the farmers (Bello and Obinne, 2012; Ugwoke, 2013). The ability of 
Creative commons User License: CC BY-NC-ND

Abstracted by: EBSCOhost, Electronic Journals Service (EJS),

Google Scholar, Journal Seek, Scientific Commons,

Food and Agricultural Organization (FAO), CABI and Scopus
Journal of Agricultural Extension

Vol. 22 (3) October, 2018

ISSN(e): 24086851; ISSN(Print); 1119944X

http://journal.aesonnigeria.org

http://www.ajol.info/index.php/jae

Email: editorinchief@aesonnigeria.org

farmers to achieve the ultimate goal of optimal production depends to a great extent on their effective utilization of available agricultural information. Agricultural information creates awareness among farmers about plants and crops species, plant diseases, existence of credit facilities, agricultural technology, innovative practices, and marketing opportunities. Mashroofa and Senevirathne (2014), stated that farmers need information to identify the cost, storage, usage, varieties of newly introduced seeds, pesticides, and weather in order to get maximum yields and best production. To be able to satisfy these needs, information must be provided for the farmers in a format most appealing and comprehensive to them (Ukachi and Ayiah, 2017).

According to Alemna (2000), rural farmers have specific needs and vary according to specific factors at hand. Information seeking behaviour of farmers is complex and requires the use of both communication and information seeking modes. The recent literature search revealed that there is need for more research efforts in the area of agricultural and nutritional information needs of farmers. Hence this study therefore was intended to fill up this gap. Specifically, the study described the personal characteristics of arable crop farmers in the study area; identified sources of agricultural and nutrition information explored by crop farmers; ascertained the agricultural information needs of arable crop farmers, and identified the nutrition information needs of the respondents.

\section{Hypothesis}

There is no significant difference in agricultural and nutritional information needs of farmers across the selected blocks in Ondo North Agricultural zone.

\section{Methodology}

The study was carried out in Ondo North agricultural zone of Ondo State. It has an area of 15,195.2 square kilometres and lies at latitude $7^{0} 55^{1}$ North and longitude $5^{0} 25^{1}$ East. The state has a population of $3,460,877$ and a population density of 218 people per square kilometre (NPC, 2006). The climatic condition in the state is favourable for the cultivation of arable crops such as maize, yam, cocoyam, cassava, plantain/banana among others.

A multistage sampling procedure was used in the selection the respondents for the study. Ondo North agricultural zone was purposively selected out of the three agricultural development programme (ADP) zones in the state based on high predominant practice of arable crops. The selected zone comprises of 8 blocks, from which $50 \%$ of the blocks were randomly selected. In the next stage $50 \%$ of the total 32 cells within the selected blocks were randomly selected making 16 cells selected for the study. Lastly, $40 \%$ of the registered arable crop farmers were randomly selected to have a total of 212 respondents that formed the sample size for this study. Interview schedule was used as instrument for data collection. Descriptive (frequency counts, percentages, Mean) and inferential statistical tool (ANOVA) were used to analyse the data generated. The dependent variable of the study was crop farmers' agricultural and nutritional information needs. This was measured on a 3-point Likert-type rating scale of highly needed $=2$; 
Creative commons User License: CC BY-NC-ND

Abstracted by: EBSCOhost, Electronic Journals Service (EJS),

Google Scholar, Journal Seek, Scientific Commons,

Food and Agricultural Organization (FAO), CABI and Scopus
Journal of Agricultural Extension

Vol. 22 (3) October, 2018

ISSN(e): 24086851; ISSN(Print); $1119944 X$

http://journal.aesonnigeria.org

http://www.ajol.info/index.php/jae

Email: editorinchief@aesonnigeria.org

moderately needed $=1$ and not needed $=0$. There are 25 items on agricultural and nutritional information with response options. The respondents were scored based on their responses on 25 items and multiplied by the rating scores. The maximum and minimum score was 50 and 0 respectively. The grand mean for each category of agricultural and nutritional information need was determined and the respondents were adjudged as needing any item of information when its mean is equal to or above the grand mean and not needed when its mean is below the grand mean.

\section{Results and Discussion}

\section{Personal Characteristics of Crop Farmers}

The mean age of the respondents was 52.2 years with range of 51and above years old constituting above half $(54.8 \%)$ of the sample size while $32.5 \%$ were between the ages of 31 and 40 years and $12.7 \%$ of them fell within the ages of 30 and 40 years. (Table 1) The result shows that adults were more involved in arable crop farming in the study area. The majority (84\%) of the respondents were married, $7 \%$ of them were separated, $5 \%$ of them were widowed while $2 \%, 2 \%$ of them were divorced and single respectively. Among the household sampled for this study, $84.0 \%$ of them were male-headed. household (Table 1).

About $57 \%$ of the sampled farmers had between 4 and 6 household size while $29 \%$ had between 7 to 9 household size and $10 \%$ had between 1 and 3 household size, others (4\%) had 10 and above household size. The mean household size was 6 members. This household size was considered to be high and may be of advantage because labour may be available for agricultural production. On the other hand, it is a reflection of a high level of dependency hence high level of poverty and food insecurity in the household since the larger the household the higher the number of mouth to be fed and vice versa. This finding agrees with the assertions of Oluwatayo (2008) and Babatunde et al (2007) that the larger the household size the more mouth to be fed.

The mean year of formal education of the respondents was 5.4. The results reveal that $41 \%$ of the respondents had no formal education while $27.9 \%$ of them had primary education and $8.0 \%$ of the respondents had tertiary education (Table 1.) The majority (75.5\%) of the respondents had years of farming experience above 10 years while $14.6 \%$ had between 6 to 10 and $9.9 \%$ had between 1 to 5 years respectively. This result suggests that the respondents have acquired more knowledge and technical ideas on how to manage farm production problems.

Table 1 shows that the majority (68.0\%) of the respondents cultivated land areas of sizes between 1.00 and 2.99 hectares of land follow by $18.8 \%$ who had farm size between 3.00 and 4.99 hectares of land while $10.4 \%$ had farm size less than 1.00 hectare and $2.4 \%$ had cultivatable farm size of between 5.0 to 6.99 hectares while the remaining $(0.5 \%)$ had 7 and above hectares of cultivatable farm size. The average cultivatable farm size was 1.94 hectares. The implication of this finding is that the majority of the respondents are small scale holders which is a characteristic of an African farmer. This finding is in 
Creative commons User License: CC BY-NC-ND

Abstracted by: EBSCOhost, Electronic Journals Service (EJS),

Google Scholar, Journal Seek, Scientific Commons,

Food and Agricultural Organization (FAO), CABI and Scopus
Journal of Agricultural Extension

Vol. 22 (3) October, 2018

ISSN(e): 24086851; ISSN(Print); $1119944 X$

http://journal.aesonnigeria.org

http://www.ajol.info/index.php/jae

Email: editorinchief@aesonnigeria.org

conformity with the finding of Ismaila (2016) which reported that the majority of farmers in South-western Nigeria, Ondo State inclusive, are relatively small scale producers. The small farm size among the majority of the respondents may however be attributed to their inadequate access to land for farming which in one hand could limit the rate of adoption of innovations that should improve production. Furthermore, $47.6 \%$ of the respondents were members of social organization within their community. This result reveals that some of the respondents have social affiliations within their communities. This could promote social networks and acquisition of information and adoption of innovations related to agriculture. Ogunremi (2012) posited that affiliation of farming households with social organizations encourages the spread and usage of communication methods for accessing agricultural information.

Table 1: Respondents personal characteristics

\begin{tabular}{|c|c|c|}
\hline $\begin{array}{l}\text { Personal characteristics } \\
\text { Age (years) }\end{array}$ & Percentage & Mean value \\
\hline $30-40$ & 12.7 & \\
\hline $41-50$ & 32.5 & 52.2 \\
\hline 51 and Above & 54.8 & \\
\hline \multicolumn{3}{|l|}{ Marital Status } \\
\hline Married & 84.0 & \\
\hline Single & 2.0 & \\
\hline Separate & 7.0 & \\
\hline Widow & 5.0 & \\
\hline Divorced & 2.0 & \\
\hline \multicolumn{3}{|l|}{ Sex } \\
\hline Male & 84.0 & \\
\hline Female & 16.0 & \\
\hline \multicolumn{3}{|l|}{ Household size } \\
\hline $1-3$ & 10 & 6 \\
\hline $4-6$ & 57 & \\
\hline $7-9$ & 29 & \\
\hline 10 and above & 4 & \\
\hline \multicolumn{3}{|l|}{ Years of education } \\
\hline 0 (no formal education ) & 41.0 & \\
\hline 1-6 (primary education) & 27.9 & 5.4 \\
\hline 7-12 (secondary education) & 23.1 & \\
\hline 13 and above (Tertiary) & 8.0 & \\
\hline \multicolumn{3}{|l|}{ Farming experience (years) } \\
\hline $1-5$ & 9.9 & \\
\hline $6-10$ & 14.6 & \\
\hline Above 10 & 75.5 & \\
\hline \multicolumn{3}{|l|}{ Farm size (hectares) } \\
\hline$<1$ & 10.4 & \\
\hline $1-2.99$ & 68.0 & 1.94 \\
\hline $3.0-4.99$ & 18.8 & \\
\hline $5.0-6.99$ & 2.4 & \\
\hline 7 and above & 0.5 & \\
\hline \multicolumn{3}{|c|}{ Membership of social organization } \\
\hline Yes & 47.6 & \\
\hline No & 52.4 & \\
\hline
\end{tabular}

Field survey 2015 
Creative commons User License: CC BY-NC-ND

Abstracted by: EBSCOhost, Electronic Journals Service (EJS),

Google Scholar, Journal Seek, Scientific Commons,

Food and Agricultural Organization (FAO), CABI and Scopus
Journal of Agricultural Extension

Vol. 22 (3) October, 2018

ISSN(e): 24086851; ISSN(Print); $1119944 X$

http://journal.aesonnigeria.org

http://www.ajol.info/index.php/jae

Email: editorinchief@aesonnigeria.org

\section{Sources of Agricultural and Nutritional Information Explored by Arable Crop Farmers}

Table 2 shows the available sources of agricultural and nutritional information. It was revealed that most $(98.6 \%)$ of the respondents seek information from extension agents followed by the use of cell phones $(92.5 \%)$, friends/neighbours $(90.6 \%)$ radio $(86.3 \%)$ television (67.9\%). Other sources of information used by the farmers were: newspaper $(22.2 \%)$ and Internet/ Email (4.1\%). This finding shows that interpersonal contacts and electronic media are explored by the respondents. Internet/email was the least source of information from which farmers seeks agricultural and nutritional information. This may be due to lack of access and infrastructure on these sources of information in the rural areas. This result confirms the finding of Owen (2008) that the most available ICT in the rural areas include cell phone, radio and television and others than Newspaper, Bulletin, Internet and E-mail which are generally low. This implies that conventional ICTs (radio, television and telephones) still remain the most available ICTs to farmers in the study area.

Table 2: Sources of agricultural and nutritional information

\section{Sources of Information Percentage $(n=212)$}

\begin{tabular}{ll} 
Cell phone & 92.5 \\
Radio & 86.3 \\
Television & 67.9 \\
Newspaper & 22.2 \\
Friends/neighbours & 90.6 \\
Internet/ E mail & 4.2 \\
Extension agents & 98.6 \\
& \\
\hline
\end{tabular}

Field survey $2015 \quad{ }^{*}$ Multiple Response

\section{Agricultural and Nutritional Information Needs of the Respondents}

The findings on agricultural and nutritional information needs of the respondents are shown in Table 3 The information needs on agricultural dimension are as follow: climate and weather forecast ( $\bar{X}=1.88$ ), location and availability of inputs (improved seeds, fertilizers, herbicides, pesticides) ( $\bar{X}=1.63)$, disease control of maize $(\bar{X}=1.50)$ and date of planting maize $(\bar{X}=1.43)$. method of pest control of maize $(\bar{X}=1.42)$, chemical application for weed control ( $\bar{X}=1.40)$, method of storage for harvested cobs ( $\bar{X}=1.39$ ), plant spacing for maize ( $\bar{X}=1.33)$, method of fertilizer application $(\bar{X}=1.32)$, land preparation method ( $\bar{X}=1.13$ ), labour availability for production $(\bar{X}=0.80)$, harvesting date of maize ( $\bar{X}=0.77)$ and information related to site selection for planting maize ( $\bar{X}$ $=0.62$ ). The agricultural information needs of the respondents are majorly those that 
Creative commons User License: CC BY-NC-ND

Abstracted by: EBSCOhost, Electronic Journals Service (EJS),

Google Scholar, Journal Seek, Scientific Commons,

Food and Agricultural Organization (FAO), CABI and Scopus
Journal of Agricultural Extension

Vol. 22 (3) October, 2018

ISSN(e): 24086851; ISSN(Print); $1119944 X$

http://journal.aesonnigeria.org

http://www.ajol.info/index.php/iae

Email: editorinchief@aesonnigeria.org

improve their production such as improved seeds, weather forecast, diseases and pest control. This implies that the information needs of respondents are majorly technical agricultural information. This agrees with the findings of Mittal et al (2010); Salau et al (2013) who reported that farmer's information needs are of mostly technical agricultural information that centred on production.

Furthermore, Table 3, reveals other agricultural information needs of respondents to include: information on market where farm produce are exchanged for other farm produce $(\bar{X}=1.55)$ and information on market days for selling maize crop produce $(\bar{X}=1.40)$ Other agricultural information needs of the respondents include: information related to market location ( $\overline{\mathrm{X}}=1.24)$ and best market time for buying and selling of other agricultural crops $(\bar{X}=1.13)$. This confirms the findings of Olowu (2011) who asserted that market information are highly essential and highly needed for rational decision making among the farming households.

Finally, the nutritional information needs of the farmers are those information related to food utilization such as information on food safety and hygiene ( $\bar{X}=1.61)$, food preparation and processing method $(\overline{\mathrm{X}}=1.28)$ and information on quality of food to be taken per meal time $(\overline{\mathrm{X}}=1.28)$. Other respondents' nutritional information needs are: quantity of food required to meet nutritional needs for individuals $(\bar{X}=1.05)$ and appropriate time of taking meal $(\overline{\mathrm{X}}=0.67)$. This implies that the information needs of the respondents are majorly nutritional education. This finding implies that the respondents are not having access to nutritional information in the study area. This finding agrees with that of Meitei and Devi (2009) that food and nutritional information as part information needs of farmers. 
Creative commons User License: CC BY-NC-ND

Abstracted by: EBSCOhost, Electronic Journals Service (EJS),

Google Scholar, Journal Seek, Scientific Commons,

Food and Agricultural Organization (FAO), CABI and Scopus
Journal of Agricultural Extension

Vol. 22 (3) October, 2018

ISSN(e): 24086851; ISSN(Print); 1119944X

http://journal.aesonnigeria.org

http://www.ajol.info/index.php/jae

Email: editorinchief@aesonnigeria.org

Table 3: Agricultural and nutritional information needs

\begin{tabular}{|c|c|}
\hline \multirow{2}{*}{\multicolumn{2}{|c|}{$\begin{array}{l}\text { Information Need } \\
\text { Agricultural } \\
\text { Information Need }\end{array}$}} \\
\hline & \\
\hline Climate and weather forecast & $1.88^{*}$ \\
\hline $\begin{array}{l}\text { Location and availability of input ( } \\
\text { improved seeds, fertilizers, } \\
\text { herbicides, pesticides) }\end{array}$ & $1.63^{*}$ \\
\hline Disease control of maize & $1.50^{\star}$ \\
\hline Planting date for maize & $1.43^{*}$ \\
\hline Method of pest control for maize & 1.42 \\
\hline $\begin{array}{l}\text { Chemical application for weed } \\
\text { control }\end{array}$ & $1.40^{*}$ \\
\hline $\begin{array}{l}\text { Method of storage of harvested } \\
\text { cobs }\end{array}$ & $1.39^{*}$ \\
\hline Plant spacing for maize & $1.33^{*}$ \\
\hline Method of fertilizer application & $1.32^{*}$ \\
\hline Land preparation methods & $1.13^{*}$ \\
\hline Labour availability for production & 0.80 \\
\hline Harvesting date of maize & 0.77 \\
\hline Site selection for planting maize & 0.62 \\
\hline $\begin{array}{l}\text { Information on market where farm } \\
\text { produce are exchanged for other } \\
\text { farm produce }\end{array}$ & $1.55^{\star}$ \\
\hline $\begin{array}{l}\text { Information on market days for } \\
\text { selling maize crops produce }\end{array}$ & $1.40^{*}$ \\
\hline Information on market location & $1.24^{*}$ \\
\hline $\begin{array}{l}\text { Best market time for buying and } \\
\text { selling of other agricultural crops }\end{array}$ & $1.13^{*}$ \\
\hline Nutritional information Need & \\
\hline $\begin{array}{l}\text { Information on food safety and } \\
\text { hygiene }\end{array}$ & $1.61^{*}$ \\
\hline $\begin{array}{l}\text { Food preparation and } \\
\text { processing methods }\end{array}$ & $1.28^{\star}$ \\
\hline $\begin{array}{l}\text { Information on quality of food to be } \\
\text { taken per meal time }\end{array}$ & $1.28^{*}$ \\
\hline $\begin{array}{l}\text { Quantity of food required to meet } \\
\text { nutritional needs }\end{array}$ & $1.05^{\star}$ \\
\hline Appropriate time of taking meal & 0.67 \\
\hline
\end{tabular}

Appropriate time of taking meal

\section{- * needed. Field Survey, 2015}

\section{Categorization of Respondents on Agricultural and Information Needs}

Figure1 reveals that close to half $(46.7 \%)$ of the respondents had low agricultural and nutritional information needs while $38.2 \%$ of the respondents were categorized as to have moderate information needs and Others (15.1\%) were of the high category.

This implies that more than half $(53.3 \%)$ of the respondents had moderate and high information needs respectively. This may be due to lack of access to such information needed through the available sources. 


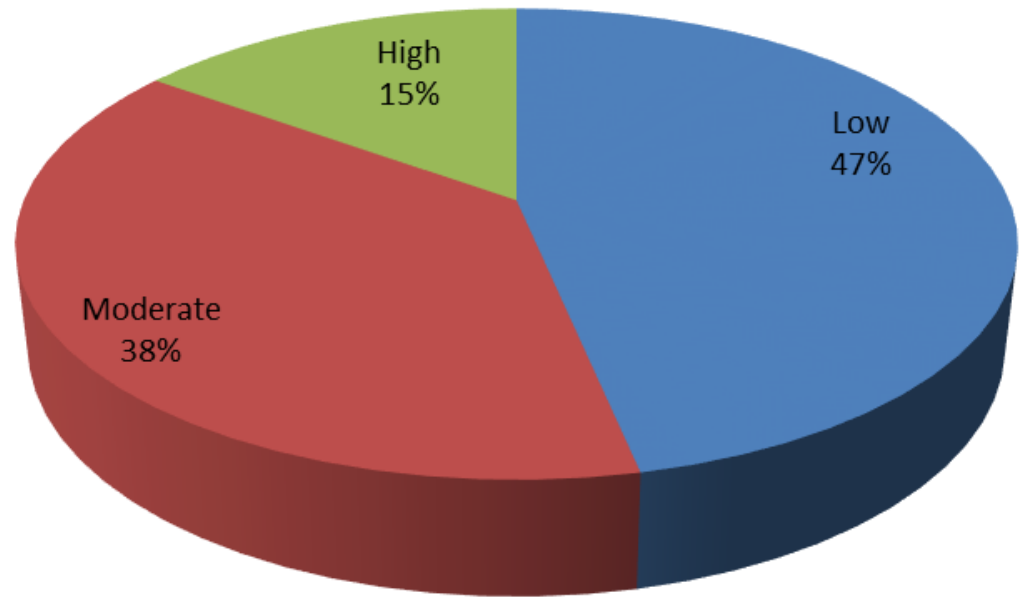

Figure 1: Pie chart showing categories of respondents according to agricultural and Nutritional information needs

\section{Difference in the Agricultural and Nutritional Information Needs Across Selected Local Government Areas in Ondo North Agricultural Zone.}

Table 4 shows that significant difference exist in agricultural and nutritional information needs across the selected Local Government Areas in Ondo North agricultural zone ( $F=$ 5.137, $\mathrm{P}<0.05)$.. This finding implies that farmers lack access to agricultural and nutritional information in the study area.

Table 4: Differences in agricultural and nutritional information needs of respondents across the selected Local Government Areas.

\begin{tabular}{llllll}
\hline Variable & $\begin{array}{l}\text { Source of } \\
\text { variance }\end{array}$ & $\begin{array}{l}\text { Sum of } \\
\text { squares }\end{array}$ & $\begin{array}{l}\text { Degree of } \\
\text { freedom }\end{array}$ & $\begin{array}{l}\text { Mean } \\
\text { square }\end{array}$ & $\mathbf{F}$ \\
\hline Agricultural & $\begin{array}{l}\text { Between selected } \\
\text { and }\end{array}$ & 655.102 & 3 & 218.367 & $5.137^{*}$ \\
$\begin{array}{l}\text { Nutritional } \\
\text { Information }\end{array}$ & Extension Blocks & & & & \\
needs & & & & & \\
& & & & & \\
& $\begin{array}{l}\text { Within selected } \\
\text { Extension Blocks }\end{array}$ & 8841.105 & 208 & 42.505 & \\
\hline Total & & & & & \\
\hline
\end{tabular}

- $\mathrm{P} \leq 0.05$. Source. Field survey, 2015 
Creative commons User License: CC BY-NC-ND

Abstracted by: EBSCOhost, Electronic Journals Service (EJS),

Google Scholar, Journal Seek, Scientific Commons,

Food and Agricultural Organization (FAO), CABI and Scopus
Journal of Agricultural Extension

Vol. 22 (3) October, 2018

ISSN(e): 24086851; ISSN(Print); $1119944 X$

http://journal.aesonnigeria.org

http://www.ajol.info/index.php/jae

Email: editorinchief@aesonnigeria.org

Table 5 reveals that agricultural and nutritional information needs of the respondents sampled from Akoko West East Local Government Area statistically differ significantly (Mean $=59.98$ ) from other three Local Government Areas in Ondo North Agricultural zone. The result further shows that agricultural and nutritional information needs of respondents from Owo, Ose and Akoko South West (Mean =56.67, 56.61 and 55.43 respectively) were the same but differ statistically from that of from Akoko North/East Local Government Area.

This implies that the respondents selected from Akoko North LGA are greatly in need of agricultural and nutritional information than other selected LGAs This finding shows that farmers from Akoko North highly lack access to agricultural and nutritional information compared to other farmers within Ondo North agricultural zone.

Table 5: Summary of differences in agricultural and nutritional information needs of respondents across selected extension blocks.

\begin{tabular}{lllc}
\hline & & \multicolumn{2}{c}{ Subset for alpha $=\mathbf{0 . 0 5}$} \\
\hline Extension Block & $\mathrm{N}$ & 1 & 2 \\
Owo & 49 & $56.67^{\mathrm{b}}$ & \\
Akoko South West & 56 & $55.43^{\mathrm{b}}$ & \\
Akoko North East & 58 & & $59.98^{\mathrm{a}}$ \\
Ose & 49 & $56.61^{\mathrm{b}}$ & \\
\hline
\end{tabular}

Source: Field Survey, 2015

$a, b-$ mean along the same row with different superscripts differ significantly at 0.05 level.

\section{Conclusion and Recommendations}

The sources of agricultural and nutritional information explored by the respondents were extension agents, mobile phones, friends \& neighbours and radio. The most agricultural information needed were; information on climate and weather conditions, location and availability of input, pest and disease control as well as planting dates for maize. Besides, information on markets where farm produce is easily exchanged for other farm produce were also needed by the respondents.

The nutritional information needed was mainly on food safety and hygiene in the study area. Across the agricultural zones, Akoko North/ east was found to be most in need of both agricultural and nutritional information.

Information dissemination should be channelled towards the identified sources and has to be related to technical, economic and nutritional education. Agricultural extension effort should be directed towards already identified agricultural zone, local government or district for justification of extension effort in which the agricultural zone can as well serve as a model for others thereby collective enhance farmers' capability for optimum 
Creative commons User License: CC BY-NC-ND

Abstracted by: EBSCOhost, Electronic Journals Service (EJS),

Google Scholar, Journal Seek, Scientific Commons,

Food and Agricultural Organization (FAO), CABI and Scopus
Journal of Agricultural Extension

Vol. 22 (3) October, 2018

ISSN(e): 24086851; ISSN(Print); $1119944 X$

http://journal.aesonnigeria.org

http://www.ajol.info/index.php/iae

Email: editorinchief@aesonnigeria.org

production. Extension service providers; government and non-governmental organizations should collaborate with health workers as an auxiliary services function to make nutritional education and information available to arable crop farmers for healthy living which will resultantly enhance the productive capacity of the farmers in the study area.

\section{References}

Adio, E.O; Abu Y; Yusufu, S.K and Nansoh, S (2016): Use of Agricultural Information Sources and Services by Farmers for Improve Productivity in Kwara State. Library Philosophy and Practice (e-journal). 1456. http://digitalcommons.unl.edu/libphilprac/1456

Alemna, A. A. and Skouby K. E. (2000). An investigation into the Information Needs and Information- seeking behaviour of members of Ghana's legislature. Library Management, Vol. 21(5): 235 -240.

Babatunde, R. O. Omotosho, O. A. and Sholotan, O.S. (2007). Factors Influencing Food Security Status of Rural Farming Households in North Central Nigeria. Agricultural Journal, 2(3): $351-357$.

Bello, M. and Obinne, C.P.O. (2012) Problems and Prospects of Agricultural Information Sources Utilization by Small Scale Farmers: A Case from Nasarawa State of Nigeria. Journal of Communication, 3(2): 91-98

Chen, Z., Liu, C. and Yang, D. (2011) Information Poverty and Farmers' Information Right in China's Mountainous Rural Areas. Procedia Engineering. www.sciencedirect.com/science/article/pii/S1877705811017371

Fahmida, H. (2015): Link Between Nutrition and Agriculture. The Daily Star News.. http://www.the dailystar.net/link-between-nutrition-and-agriculture

Ismaila, O.K (2016): Contributions of Information And Communication Technology Usage to Household Food Security among Maize Farmers In Ondo State, Nigeria. An Unpublished Thesis in the Department of Agricultural Extension and Rural Development, Ladoke Akintola University of Technology, Ogbomoso, Nigeria. $152 \mathrm{pp}$

Mashroofa and Senevirathne (2014) Influence of Information Literacy skills in accessingagricultural information: with special reference to paddy farmers of 
Creative commons User License: CC BY-NC-ND

Abstracted by: EBSCOhost, Electronic Journals Service (EJS),

Google Scholar, Journal Seek, Scientific Commons,

Food and Agricultural Organization (FAO), CABI and Scopus
Journal of Agricultural Extension

Vol. 22 (3) October, 2018

ISSN(e): 24086851; ISSN(Print); 1119944X

http://journal.aesonnigeria.org

http://www.ajol.info/index.php/jae

Email: editorinchief@aesonnigeria.org

Ampara district,Sri Lanka. Being a paper presented during the IFLA conference held in Lyon.

Available at: library.ifla.org/1003/1/140-mashroofa-en.pdf.

Mchombu, K. J. (2006). Libraries, literacy and poverty reduction: a key to African Development. A research paper looking at libraries in Africa Commissioned by Book Aid International and sponsored by the Commonwealth Foundation

Mittal, S., Gandhi, S. and Tripathi, G. (2010). Socio-economic impact of mobile phones on Indian agriculture. Indian Council for Research on International Economic Relations New Delhi.

Meitei, S.L and devi, Th. P (2009): Farmers information Needs in Rural Manipur: An Assessment. Annals of Library and Information Studies 56: 35-440

National Population Commission(NPC) (2006). Fact sheet for Nigeria Population. Retrieved from URL: www/npc.org/population htm.

Olajide B.R (2011): Assessment of farmers' Access to Agricultural Information on Selected Food crops in Iddo District of Oyo State Nigeria. Journal of Agriculture and Food Information 12(3-4) : $354-363$.

Ogunremi, J.B. (2012). The Effect of Farmers' Personal Characteristics and Contact withExtension Agents on Technology Linkage Activities in Oyo State. Journal of Agriculture, Forestry and the Social Sciences (JOAFSS), Vol. 10(2): 67 - 72

Olowu, T.A. (2011): Assessment of Agricultural Information Needs For CTA's Product and Service in Africa, Caribbean and Pacific (ACP) State - Country Study: Nigeria Available on [www.cta.int].

Oluwatayo I.B (2008). Explaining inequality and Welfare status of Households in rural Nigeria: Evidence from Ekiti state; Humanity and Social Science Journal 3 (1): 70 80,2008

Owen, D. (2008). Training workshop on ICT for rural development: Access andapplication. USAID ICT4D program. Available at: http://go.World bank.org/XL89032600.

Salau E.S; Saingbe N.D and Garba M.N (2013): Agricultural Information Needs of Small Holder Farmers in Central Agricultural Zone of Nasarawa State. Journal of Agricultural Extension 17(2): 113- 121

Ugwoke, B. U. (2013) Promoting Nigerian Agriculture through Library and Information Services. International Journal of Information Management, Vol. 33: 564-566. Available at: www.sciencedirect.com/science/article/pii/S0268401213000352.

Ukachi, N. B. (2007) "Information Needs, Sources and Information Seeking Behaviour of Rural Women in Badagry, Lagos, Nigeria". Information Trends. Vols. 4 \& 5 . 
Creative commons User License: CC BY-NC-ND

Abstracted by: EBSCOhost, Electronic Journals Service (EJS),

Google Scholar, Journal Seek, Scientific Commons,

Food and Agricultural Organization (FAO), CABI and Scopus
Journal of Agricultural Extension

Vol. 22 (3) October, 2018

ISSN(e): 24086851; ISSN(Print); 1119944X

http://journal.aesonnigeria.org

http://www.ajol.info/index.php/jae

Email: editorinchief@aesonnigeria.org

Ukachi, N.B. (2015) "Exploration of information literacy skills status and impacts on the quality of life of artisans in Lagos, Nigeria", New Library World, 116 (9/10): 578 587 Available at: http://dx.doi.org/10.1108/NLW-01-2015-0006.

Ukachi, N. B and Ayiah, E.M. (2017) "Exploration of Appropriate Media for Satisfying the Information Needs of Future Community of African Farmers" (2017). Library $\begin{array}{llll}\text { Philosophy and Practice } & 1513 .\end{array}$ http://digitalcommons.unl.edu/libphilprac/1513 